\title{
Language Needs Analysis: An Initial Investigation on Malaysian Drivers for Alternative Taxi Company
}

\author{
Siti Noor Diana Mohd Kamaruddin ${ }^{1}$, Zulaikha Farhana Izehari ${ }^{2} \&$ Ira Syaqira Sukimin ${ }^{2}$

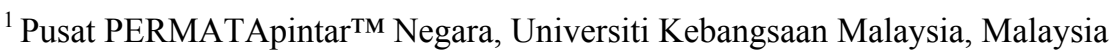 \\ ${ }^{2}$ Faculty of Education, Universiti Teknologi MARA, Malaysia \\ Correspondence: Siti Noor Diana Mohd Kamaruddin, Pusat PERMATApintar ${ }^{\mathrm{TM}}$ Negara, Universiti Kebangsaan \\ Malaysia, Malaysia.
}

Received: July 21, 2017

doi:10.20849/ajsss.v2i4.239
Accepted: November 28, 2017 Online Published: December 8, 2017

URL: https://doi.org/10.20849/ajsss.v2i4.239

\begin{abstract}
Alternative taxi service has started becoming a trend and gained popularity all over the world. In Malaysia, people depend on conventional taxis for many decades which are registered under Public Transport Commission. With the advancement of technology, a few applications were introduced and passengers and conventional taxi drivers started installing them to accept or reject passengers. However, when the popular American alternative taxi service (Uber) arrived in Malaysia, it has become popular among passengers when new drivers emerged as many people started registering and using the application. The study attempts to explore the language needs of Malaysian taxi drivers (particularly alternative taxi service) and the challenges they face when communicating in the English Language with their passengers. A case study design was employed in the study which a total of three participants (part-time drivers living in Klang Valley area, registered under the same alternative taxi company in Malaysia) were interviewed through open-ended and semi structured interview questions. The findings show there are three main challenges faced by these drivers when communicating in English Language with their passengers which are (1) struggle to comprehend communication in English Language with native speakers, (2) difficulty in making conversations and keeping them going, and (3) difficulty in understanding and communicating with non-native speakers from non-English Language speaking countries. Another findings show that the English Language is used with passengers for four reasons: (1) using English Language to reply passengers' text message, (2) using English Language to spark general conversation with passengers, (3) using English Language to communicate with foreign passengers; and (4) using English Language to convey precise information to passengers. Therefore, alternative taxi companies should consider offering courses related to enhancing their drivers' competency in English communication. English courses developed explicitly for the purpose of communication between drivers and passengers may take the results found from this study into account. The findings should be able to assist in developing a course that would aid drivers into strategizing their communication with passengers.
\end{abstract}

Keywords: alternative taxi drivers, English language competency, needs analysis

\section{Introduction}

Over the past few years, alternative taxi service has started becoming a trend and gained popularity all over the world. There are a few services often used in the United States as reported by Steinmetz (2014) such as Lyft, Sidecar, Flywheel, Curb, Hailo, RubyRide and Shuddle. Each company offers different services and a few cater to specific passengers. For instance, Shuddle provides services only to assist parents to pick up or take their children to school or sports practice. This has helped parents enormously especially those who are working. In Malaysia, people depend on conventional taxis for many decades which are registered under Public Transport Commission. The taxi drivers are registered under legit taxi companies such as Blue Cab, Sunlight and Airport Limo. There are also circumstances where drivers are given their own permit and they do not have to apply for the permit through taxi companies. With the advancement of technology, a few applications were introduced and passengers and conventional taxi drivers started installing them to accept or reject passengers. For instance, Ezcab, TaxiFareFinder and MyTeksi. These applications were only meant for conventional taxi drivers. However, when the popular American alternative taxi service (Uber) arrived in Malaysia, it has become popular among passengers when new drivers emerged as many people started registering and using the application. At the moment, Uber offers services throughout Selangor and Kuala Lumpur and certain areas in Malacca and Negeri Sembilan. 


\subsection{Research Problem}

Bhar, Bakar and Eng (2012) concluded one of the factors that contribute to a service industry to lose its business is due to communication and language barriers which bring to a halt in meaningful interaction process. This may lead to misunderstanding and later might evoke dissatisfaction among customers. Several cases, for instance, have been reported regarding disputes between alternative taxi drivers and passengers. In Kuala Lumpur, a driver punched his passenger due to a misunderstanding from the passenger's request to use a toll-free route (Malaysian Digest, 2017). Another case also involved physical assault when a driver mistook the instructions from a passenger in Puchong (Malay Mail Online, 2017). These mentioned cases are caused by miscommunication between the drivers and passengers which surely may have been easily avoided with enhanced language skills for the drivers. Despite such incidents, alternative taxi services remain as top choice of transportation by urban Malaysians (Nur Khairah, 2017). Thus, it should be wise to review communication and language barriers and ways to overcome them in order to improve alternative taxi services in Malaysia.

In Australia, Combined Communication Networks provides free English Language and Literary courses for the taxi industry. The courses are carried out three hours per week for nine weeks where they focus on improving workplace English Language skills, communication, confidence and customer service. The courses have proved to build confidence among those involved in taxi industry. However, locally, Bhar et. al (2012) explained that no study has yet to be conducted on how Malaysian companies deal with language problems at the workplace. Hence, this has motivated the present research to investigate necessary steps that can be done to help alternative taxi drivers cope with the challenges they face when communicating in the English Language by studying how they use the English Language with their passengers.

\subsection{Purpose of the Study}

Since there has not been any study conducted on the language needs of Malaysian taxi drivers (particularly alternative taxi service), this study is conducted to explore the challenges the drivers face when communicating in the English Language with their passengers. As mentioned above, the service is only provided throughout Selangor and Kuala Lumpur and certain parts of Malacca and Negeri Sembilan which can be considered as urban areas and tourists attractions in Malaysia. Thus, it will be highly beneficial for alternative taxi drivers to know how to cater to their passengers so they will not lose their business because of communication and language barriers. From the data collected on how the English Language is used by alternative taxi drivers, the researchers will find out the language needs and a module or training can be developed to aid these drivers to become more competent speakers in delivering services.

\subsection{Research Objectives}

The research objectives of this study are as follows:

i. To investigate the challenges faced by alternative taxi drivers when communicating in the English Language with their passengers.

ii. To find out how alternative taxi drivers use the English Language with their passengers.

\subsection{Research Questions}

The research questions of this study are:

i. What are the challenges faced by alternative taxi drivers when communicating in the English Language with their passengers?

ii. How do alternative taxi drivers use the English Language with their passengers?

\subsection{Significance of the Study}

It is utmost important to investigate the challenges faced by alternative taxi drivers when communicating in the English Language with their passengers. The findings of this study will help the alternative taxi company and new drivers to realize the challenges that the present drivers are facing and come up with strategies and ways to assist them in overcoming these challenges. The alternative taxi company could also learn what can be done to prepare these drivers to become skilful and acquire the competency to be able to communicate meaning with their passengers. Hence, it is essential to know the reality and challenges that the drivers re dealing with and assistance can be provided to them.

Furthermore, this study tends find out how alternative taxi drivers use the English Language with their passengers to comprehend their skills and levels of competency in communicating in the English Language. The analysis on the usage of the English Language can determine their level of mastering the basic concepts of English Language 
for communication purpose; it can really help in developing specific trainings or modules to help them become better speakers. Thus, it is vital to study whether the drivers' use of the English Language so module and trainings developed can cater to their needs and new or potential drivers later.

\section{Literature Review}

\subsection{Language Needs Analysis}

The acronym ESP for English Language for Specific Purpose is meant for a way English language taught with a more restricted focus, which attention is given to a particular field of human activity (Wright, 1992). In other words, it is a way of teaching or learning the English language to a group of people doing specific job or activity that requires them to be able to acquire the language for specific purpose which is related to their work demand. The content of the teaching of ESP must meet learner needs regardless of what contexts the learners are in; academic, professional body or occupation. According to Strevens (1988, as cited in Javid, 2013), there are four absolute and two variable characteristics that define ESP. Absolute characteristics mentioned by Strevens must have the followings:

- designed to meet specific needs of the learner;

- related in content to particular disciplines, occupations and activities;

- centered on the language appropriate to those activities;

- $\quad$ in contrast with General English Language.

He further explained two variable characteristics that ESP may possess, but is not necessary are:

- $\quad$ restricted as to the language skills to be learned

- $\quad$ taught according to pre-ordained methodology.

Streven's definition of ESP through its characteristics was later modified by Dudley Evans and St. John (1988), but it still focuses on catering to learners needs in order to meet the objectives when learning language only for specific purpose. Dudley Evans and St. John (1988) added four variable characteristics and in contrast with Strevens', they omitted the fourth characteristic in the absolute characteristic. ESP is defined as follows according to Dudley Evans and St. John (1988):

\section{Absolute Characteristics}

- designed to meet specific needs of the learner

- makes use of the underlying methodology and activities of the discipline it serves;

- centered on the language, skills, discourse and genres appropriate to the activities

Variable Characteristics

- may be related to or designed for a specific purpose

- may be used in specific trainings or teaching situations

- $\quad$ is likely to be designed for adult learners

- $\quad$ is generally designed for intermediate or advanced students

- most ESP courses assume some basic knowledge of the language system.

From the definitions given above, many courses or training organizers have created series of modules or workshops to provide aid for people who share common goals to fulfil demand from activity or various disciplines they are in which can be achieved through the acquisition of English Language. In other words, the reason for them to learn the language depends on what they want to achieve. In this present study, the researchers refer to Dudley Evans and St. John's definition to develop a training module for the Malaysian taxi drivers.

\subsection{Alternative Taxi Company in Malaysia}

As Malaysian economy is getting more challenging each day, 100,000 more alternative taxi drivers are expected to hit Malaysia streets in 2016 (Lee, 2016). Although the additional of alternative taxi drivers is due to challenging economy, alternative taxi has become more popular in Malaysia as a lot of people living in the city demand for it. What is alternative taxi exactly? It is synonymous with taxis as alternative taxi connects drivers and riders based on referral service through smartphone application (Pullen, 2014). Application taxi users see it as a way to reduce the cost of owning vehicles because they could just call a driver to fetch them up at a specific location without much hassle. (NEM, 2014 Khazanah Research Institute, 2015) Not only it allows people to reduce the cost of owning 
vehicles, alternative taxis in Malaysia offers a cheaper fare for each ride to its passengers than fare offered by normal taxis. Elliot (2014) added that the cheap fare is possible because alternative taxi companies do not have to pay for overhead costs that normal taxi companies have to pay every year since alternative taxi has the concept of sharing a ride or carpooling. There are two application taxi companies in Malaysia; Uber and Grabcar. The two alternative taxi companies offer the same concept but different pricing as Grabcar offers its customers a flat rate price whereas Uber estimates a price range for each ride to its customers. As demands for alternative taxi service keep rising in Malaysia especially in big cities such as Kuala Lumpur, Penang, and Johor Bahru, the normal taxi demands are getting lower day by day. The operator of Big Blue Taxi Services insisted that alternative taxis and normal taxis are in direct competition with one another and claimed that taxi operators offer better deals to passengers as they are cheaper and safer. (Palansamy, 2016) In the same article, Karun Arya (Uber communications head for India and South Asia) defends alternative taxi by stating that alternative taxi and normal taxi are not competing on the same turf as the nature of alternative taxi business is about "ride-sharing", which means it does not compete with regular taxis for customers. Before alternative taxi, Malaysia has made way for MyTeksi mobile application to connect drivers with potential passengers nearby. Unlike alternative taxi services, MyTeksi offers registered taxi drivers to its customer. On the other hand, alternative taxi matches passengers with independent contractors (basically anyone registered with alternative taxi companies and has a car) (NEM, 2015). Although the price difference between normal taxi and alternative taxi make people choose the later, it is the service that people go for. Recently, Uber has tested out cash payments in Kuala Lumpur with hopes to provide all Malaysians more choice and payment option that suits people's needs (Yi Liang, 2016). Due to high demand of taxi application around the world, there has been much speculation over the last few years as to whether the so-called "sharing economy" will positively or negatively impact the future of work (Hall \& Krueger, 2015). When there is no demand for normal taxi, how do the drivers survive? In some countries, Uber is fighting to stay as law authorities see it as an unlicensed, unregulated taxi service (Elliott, 2014). But in Malaysia, alternative taxi service is staying as its demand permits it to stay for now. Regardless of one's view of alternative taxi, the sharing economy is being viewed as something that would bring about transformative change to how things are done (NEM, 2014 Khazanah Research Institute, 2015). As demands for alternative taxi keep rising in Malaysia, Uber and Grabcar are competing for better services. This means alternative taxi drivers must be efficient and good in order to make customers keep using their services. Besides ensuring safety and smooth ride from point A to point $\mathrm{B}$, drivers of alternative taxi must also be able to connect with their passengers - make the passengers feel comfortable by communicating with them.

\subsection{Communicative Competence of English Language in Alternative Taxi Community}

Communicative competence is the aspect of competency that enables language users to convey and interpret messages and to negotiate meanings within specific contexts (Hymes, 1972). It is "relative, not absolute, and depends on the cooperation of all the participants involved" (Savignon, 1983, pg. 9). In short, communicative competence is defined as the ability to ensure that both conveyor and receiver of a conversation comprehend the meaning of the message. The discourse is not only limited to speaking and listening but also in writing and reading as such observed in the uses of social media these days (Bhar, Bakar, \& Eng, 2012).In order for tourism-based organizations like public drivers, in this case, to develop their tasks effectively for their passengers, they are required to have excellent competency in communication (Selke, Hoon, \& Schaar, 2015). Likewise, drivers for alternative taxi companies should acquire good communication skills as the purpose of their tasks are similar. General taxi drivers and drivers for alternative taxi company receive passengers from various backgrounds yet urban community prefer to opt for the latter (NEM, 2014; Khazanah Research Institute, 2015). Despite the difference, the purpose of communication between them is directed to the same goal: to execute the task of transporting passengers from one point to another.

In a way, the most prominent similarity between drivers and passengers who commute under the administrations of alternative taxi companies are they depend on mobile applications in their smartphones. Therefore, all of them are driven with that common trait of which they come from urban community with the access of mobile internet and smartphones (Booton, 2014). Mercer (2000) explained that an essential requirement of conversational interaction is the concept of joint knowledge formation from shared background experiences. Shared background knowledge should then be a plus point for drivers and passengers in this context to participate in a conversation and relate to the discussed topics (Middleton \& Edwards, 1990). The importance of competent communicative skills for drivers of alternative taxi community lies on their position as the representative of the company and the country. This means that their ability to communicate and serve will highly affect the perception of public (passengers) towards their service and attitude (NEM, 2014 Khazanah Research Institute, 2015). In Malaysia, despite the growing number of tourists and expatriates visiting the country, the number of hospitality courses for public drivers remain 
underexplored (Ahmad Azmi \& Mohd Safar, 2009). With English Language becoming most common language used for communication purposes or lingua franca (Bobanovic \& Grzinic, 2011), alternative taxi company should seize the opportunity to equip their contract drivers with adequate English Language communication skills competency to improve their service. For alternative taxi drivers, passengers are able to rate their skills and attitudes on their profiles assigned to them in the respective mobile application for the company (Rundle, 2014). Several course outlines aiming to assist taxi drivers in improving their English Language communication skills have common emphases on the possible general conversations between drivers and passengers. These conversation areas are categorized into themes such as greetings, destination, clarifications, requests, traffic conditions, fares, farewell wishes, small talks and possible replies from passengers (Essberger, 2015). These are the common themes as part of English language needs preparation for taxi drivers to apply when executing their tasks. The construct of communicative competence is divided into two components with two subcategories in each component (Canale \& Swain, 1980; Canale, 1983). The two major components are linguistic and functional competence with grammatical and discourse competence embedded in the first one and sociolinguistic and strategic competence inserted in the next. Seeming that most conversational transactions that occur between drivers and passengers of alternative taxi company are temporary, functional communicative competence may have to play a larger role in serving the purpose of communication. Sociolinguistic competence requires "an understanding of the social context in which language is used" (Savignon, 1983, pg. 37). Language users, in this context are drivers, with good competency of sociolinguistic competence would be able understand the sensitivity towards dialect or variety, register, naturalness as well as cultural references addressed by their passengers. On the other hand, strategic competence is the "verbal and nonverbal communication strategies used to compensate breakdowns in communication" (Canale \& Swain, 1980, pg. 30). With strategic competency, drivers would able to cope with insufficient competency from the passengers with strategies such as paraphrase, guessing and others.Despite the emphases on functional competency of drivers' communication, it is important to note that grammatical and discourse competency would be significant when drivers for alternative taxi company interact with their passengers specifically on text messages or forums. Grammatical competence encompasses "knowledge of lexical items" and grammatical rules (Canale \& Swain, 1980, pg. 29) whereas discourse competence is the ability to connect sentences to make meaning (Brown, 2007). With linguistic competency, drivers would be able to convey messages to passengers clearly and accurately thus reducing the impact of miscommunication when serving passengers.

\section{Methodology}

The study used qualitative approach to develop the instrument, data collection procedure, and data analysis method. The detailed qualitative accounts often produced in case studies not only help to explore or describe the data in real-life environment but also help to explain the complexities of real- life situations which may not be captured through experimental or survey research (McDonough \& McDonough, 1997). Thus, to attain a better understanding of the phenomenon, the researchers employed case study design for the study as this design allows researchers to develop an in-depth analysis of the challenges faced by alternative taxi drivers in communicating with their passengers using English language. A total of three participants were involved in the study. All three participants are part-time drivers living in Klang Valley area, registered under the same alternative taxi company in Malaysia. Purposeful sampling technique was used to choose the three participants for the study as the researchers wanted to develop a detailed understanding of the phenomenon through the participants. Two of the participants are male aged 25 and another one participant is a 26 year old female. The study used interview method to collect data from the participants. The interview questions were adapted from Wozniak (2010) and later improvised to know the challenges faced by the three participants in using English language for communication purpose during work and it is beneficial for the researchers to understand the depth of the issue. This is in line with Creswell (2014) that interview in a qualitative approach helps researchers understand how individuals have personally experienced a situation and it gives more meaning in theorizing people within the contexts in which they live in (Willig, 2001). The questions were designed open ended and semi-structured for the interview for the study. A focus group interview was done to explore the challenges faced by alternative taxi drivers in communicating with their passengers using English language. The three participants were gathered together on $5^{\text {th }}$ April 2016 and the focus group interview took around an hour to gather the necessary data from all participants. The main reason behind doing a focus group interview instead of a one-on-one interview is to reduce the tense from formality and participants are able to share their experiences alternately as in a discussion. The interview was recorded using a laptop that has audio recorder software. 


\section{Findings}

4.1 What Are the Challenges Faced by Alternative Taxi Drivers When Communicating in the English Language with Their Passengers?

Based on the transcript of the interview, there are three main challenges faced by these drivers when communicating in English Language with their passengers which are (1) struggle to comprehend communication in English Language with native speakers, (2) difficulty in making conversations and keeping them going, and (3) difficulty in understanding and communicating with non-native speakers from non-English Language speaking countries. The evidences extracted from the interview are divided into three sections in attempt to answer the study's first research question.

4.1.1 Struggle to Comprehend Communication in English Language with Native Speakers

All three participants agreed they struggled to comprehend communication in the English Language when speaking with native speakers. They found different and thick accents seemed to be an obstacle for them to make meaning and they have to really concentrate on the conversation to be able to participate in the conversation. This was mentioned by one of the participants:

"I encounter quite a few times already... Native speakers... One of them... Emm... From Singapore but accent is like Australian. Kind of hard to understand. Erm... But he insists that he wants to talk...."

(Irdina)

The same situation was also mentioned by another participant. He said

"It's pretty hard actually. I had a rider from... I don't know, UK and their accent are very thick, is it? Very hard to understand... I can understand but I need to focus"

(Lutfi)

4.1.2 Difficulty in Making Conversations and Keeping Them Going

All three participants agreed they found it was difficult starting conversations in English Language with their passengers because they could not find topic of interests. They stated that conversation is normally uninteresting and they talk about the same topic with almost every passenger. They would use the same topic as conversation starter and went on silent if passengers did not reply with another question for them to able to keep the conversations going. One of the participants mentioned:

"Usually my... Conversation starter would be... It would be the same each time. Err... You always use Uber to go anywhere? And then they will reply yeah. And that's my script all the time."

(Haikal)

Thus, it can be concluded that all participants used the same topic of conversation and did not create a different one because it is a lot easier for them each time they receive new passengers.

4.1.3 Difficulty in Understanding and Communicating with Non-Native Speakers from Non-English Language Speaking Countries

It was established by all three participants they found it was even more challenging for them to communicate in the English Language with non-native speakers from non-English Language speaking countries. They stated that interaction would be limited due to language barriers so they could not really build rapport with their passengers. It became an obstacle for them to take these passengers to their desired location for all of them experience the same difficulty in explaining where to go and the drivers have a hard time understanding it. One of the participants mentioned:

"I fetched a rider from KLIA and the family is from China, like mainland China and emm... I can say that they... I mean the wife... I think she cannot speak in English Language at all and the husband probably can speak very basic English Language. So, it's kind of really hard... to speak to them. You know, trying to ask how long will they be here and what place do they want to go. So... They just give me name of places like... Penang, Melaka"

(Lutfi)

Haikal agreed with Lutfi's statement and mentioned:

"I have some experience with Japanese. Their English Language is quite funny. I need to... I need them to repeat a few times before I can catch what actually they are trying to say. Err... But in the end, I still understand what they are trying to say. It's just that if they are able to speak well, then we can save a lot of time and... The conversation would be easier."

(Haikal)

Thus, these results suggest that alternative taxi drivers share common challenges when using the English Language to communicate with their passengers. 


\subsection{How Do Alternative Taxi Drivers Use English Language with Passengers?}

Based on the transcript of the interview, the three participants use English Language with passengers for four reasons: (1) using English Language to reply passengers' text message, (2) using English Language to spark general conversation with passengers, (3) using English Language to communicate with foreign passengers; and (4) using English Language to convey precise information to passengers. The evidences taken from the interview are divided into four sections in attempt to answer the study's second research question.

\subsubsection{Using English Language to Reply Passengers' Text Message}

From time to time, alternative taxi drivers will have to communicate with their passengers through text messages to confirm exact pick up location, pick up time, and sometimes to verify passengers' identity. Irdina confirmed it by stating:

\section{"As for me, I do reply rider's text because they text me that they wait at the lobby so, I reply okay, will arrive in 5 minutes. So basically I reply in English Language."}

\subsubsection{Using English Language to Spark General Conversation with Passengers}

Based on the answers given by the participants, it is understood that alternative taxi drivers would ask a question to look like they are inquiring on reasons they use alternative taxi service rather than conventional taxi service. If the passengers keep on talking, the drivers will also continue conversing with the passengers. Haikal mentioned:

"Usually my... Conversation starter would be... It would be the same each time.

Err... You always use alternative taxi X to go anywhere? And then they will reply

yeah. And that's my script all the time. And then I wait for their response. If

they are interested in talking, then I will ask more questions. Just to make it a two

way conversation. Not just I'm asking and they reply."

\subsubsection{Using English Language to Communicate with Foreign Passengers}

Another reason for the alternative taxi drivers to use English Language is because they want to communicate with foreign passengers. During the interview, one of the participants said that it is normal for foreigners to be using alternative taxi service because they already have online accounts and have used the service back in their own country. Lutfi shared his experience in using English Language to communicate with foreign passengers after knowing that there are foreigners who use alternative taxi service in Malaysia. Below is the conversation he usually had with his foreign passengers:

"I had a rider from... I don't know, UK and their accent are very thick, very hard

to understand. I can understand but I need to focus."

\subsubsection{Using English Language to Convey Precise Information to Passengers}

English Language is extremely important as alternative taxi drivers need to deliver or convey precise information to their passengers. There are times whereby the drivers need to inform their passengers of the change of route taken and estimated time to arrive at the destination. One of the participants said that as long as the driver can understand what the passenger is saying and passenger too can understand what the driver is saying, it is already enough for both parties. The researcher then added another question regarding this matter and below is the respond from the participants:

"I use Waze a lot and if they insist on using other routes, or preferred ways, then okay. But before we get to them, they need to describe to us where is the exact location. So that is one of the toughest part to. If you're not familiar with the place, and they don't explain properly, so if you're not from there, it's hard for you to understand where is it. You need them to provide you right, very good explanation about the place."

(Lutfi)

This proves that alternative taxi drivers do use English Language to convey information and messages to their passengers. One does not have to be fluent in English Language to be able to convey messages or information to their passengers, but sufficient proficiency is needed so that the intended messages or information would be conveyed correctly.

\section{Conclusion \& Recommendations}

\subsection{Drivers' Communication with Passengers: The Use and Challenges of English Language}

The conducted interview basically attempted to explore the use and challenges of English language in communication between drivers of alternative taxi companies and their passengers. Based on the interview conducted on the three alternative taxi drivers, it is found that they mostly use English when communicating with passengers for the purpose of replying their text message, initiating conversation with them, communicating with 
foreign passengers and conveying precise information to them. Additionally, the drivers interviewed also addressed the challenges of using English language with their passengers that include understanding conversation with native English speakers, communicating with foreign passengers from non-English speaking countries and keeping the conversations going with passengers. Generally, the findings portrayed that the passengers who opt to use the service from alternative taxi companies mainly use English as their communicative language which is synonymous with English Language becoming most common language used for communication purposes or lingua franca (Bobanovic \& Grzinic, 2011). The direction of these findings points towards the importance of equipping taxi drivers with the competency to communicate in English as suggested by Ahmad Azmi \& Mohd Safar (2009). Thus, this highlight the needs for alternative taxi companies to seize the chance and provide specific course in enhance their drivers' English competency. Furthermore, the drivers mentioned about the challenge in understanding conversation with native English speakers as well as foreign passengers from non-English speaking countries. A barrier to effective communication is basically anything that prevents the receiver from understanding the senders' message (Brounstein, Bell \& Smith, 2007). In this case, most Malaysian speakers speak in Malaysian-English whereas the passengers may not be familiar with Malaysian-English, let alone Bahasa Malaysia. Thus, these challenges reveal the significance of explaining to drivers from alternative taxi company on coping strategies in communicating with passengers whose English language is difficult to comprehend. Apart from that, it has also been underlined that drivers of alternative taxi company may need to communicate with their passengers through text messages and convey precise information to them. These tasks require the drivers to be competent linguistically whereby there is a need to use exact lexical and grammatical features to convey the message accurately (Brown, 2007). Hence, this expresses the importance of addressing linguistic competency in using English language to communicate excellently with passengers.

The findings from this study portray a great deal of importance for alternative taxi companies in equipping their contract drivers with competent English language communicative skills in order to serve and cater to passengers. It is even more crucial for them seemingly that there are growing numbers of contract drivers to cater more passengers specifically those from urban areas and foreign lands who prefer to communicate in English. Therefore, alternative taxi companies should consider offering courses related to enhancing their drivers' competency in English communication. Besides, contract drivers for alternative taxi companies might as well individually attend English courses to enhance their ability to communicate in English not only for the purpose of their job as drivers but also personal improvement in learning. English courses developed explicitly for the purpose of communication between drivers and passengers may take the results found from this study into account. The findings should be able to assist in developing a course that would aid drivers into strategizing their communication with passengers.

\section{References}

Ahmad Azmi, M. A., \& Mohd Safar, H. (2009). Marketing Malaysia to the Middle East Tourists: Towards A Preferred Inter-regional Destinations . International Journal of West Asian Studies, 39-53.

Bhar, S. K., Bakar, N. A., \& Eng, C. Y. (2012). Language Barriers: Feedback from the IT Industry. Jorunal of Technical Education \& Training, 9-20.

Bobanovic, M. K., \& Grzinic, J. (2011). The importance of English language skills in the tourism sector: A comparative study of students/employees perceptions in Croatia. Journal of Tourism, Culture and Territorial Development, 10-23.

Booton, J. (2014, November). Sick of Uber? Here are 27 alternatives. Retrieved from Market Watch: http://www.marketwatch.com/story/dont-want-to-call-an-uber-this-weekend-try-these-instead-2014-11-21

Brown, H. D. (2007). Principles of Language Learning and Teaching. San Francisco: Pearson Education Inc.

Canale, M. (1983). From Communicative Competence to Communicative Language Pedagogy. Language and Communication, 2-27.

Canale, M., \& Swain, M. (1980). Theoretical Bases of Communicative Approaches to Second Language Teaching and Testing. Applied Linguistics, 1-47. https://doi.org/10.1093/applin/I.1.1

Dawes, L. M. (2000). Thinking Together: A Programme of Activities for Developing Thinking Skills at KS2. Birmingham: The Questions Publishing Company.

Dudley-Evans, A., \& St. John A., M. (1998). Developments in English Language for Specific Purposes: A Multi-disciplinary Approach. Cambridge: Cambridge University Press.

Elliott, J. (2014, October 8). 2016 Bell Media. Retrieved April 21, 2016, from CTV News: www.ctvnews.ca

Essberger, J. (2015). English for Taxi Drivers. Retrieved from English Club: https://www.englishclub.com/english-for-work/taxi-drivers.htm 
Hall, J., \& Krueger, A. (2015). An Analysis of the Labor Market for Uber's Driver-Partners in the United States. 2016 Uber Technologies Inc., 1-29.

Hymes, D. H. (1972). On Communicative Competence. Baltimore: Penguin Education, Penguin Books Ltd.

Javid, C. Z. (2013). English LAnguage for Specific Purposes: Its Definition, Characteristics, Scope and Purpose. European Journal of Scientific Research, 138-151.

Lee, P. (2016, January 4). 1995-2016 Star Media Group Berhad. Retrieved April 19, 2016, from The Star Online: http://www.thestar.com.my/

Malay Mail Online. (2017, August 13). Grab driver arrested for alleged assault of passenger. Retrieved from Malay Mail Online: http://www.themalaymailonline.com/malaysia/article/grab-driver-arrested-for-alleged-assault-of-passenger\# ijORUHMXKZbBpo6t.97

Malaysian Digest. (2017, August 14). GrabCar Driver Loses It And Punches His Passenger On Her Face. Retrieved from Malaysian Digest: http://malaysiandigest.com/features/692567-grabcar-driver-loses-it-and-punches-his-passenger-on-her-face. html

Middleton, D., \& Edwards, D. (1990). Chapter 7. In D. Middleton, \& D. Edwards, Collective Remembering (pp. 120-138). London: Sage Publications.

NEM. (2015, October 15). 2014 Khazanah Research Institute. Retrieved April 21, 2016, from Khazanah Research Institute: www.krinstitute.org

NEM. (2015, September 30). 2014 Khazanah Research Institute. Retrieved April 19, 2016, from Khazanah Research Institute: www.krinstitute.org

Nur Khairah, A. S. (2017, June 15). Uber, Grab remain preferred mode of transport. Retrieved from Free Malaysia

Today: http://www.freemalaysiatoday.com/category/nation/2017/06/15/uber-grab-remain-preferred-mode-of-transp ort/

Palansamy, Y. (2016, January 12). 2016 Malay Mail Online. Retrieved April 19, 2016, from Malay Mail Online: www.themalaymailonline.com

PEMUDAH. (2012). Your Business Our Priority. Retrieved from Public-Private Sector Collaboration towards a Globally

Competitive

Malaysia: http://www.pemudah.gov.my/documents/10124/37722/PEMUDAH+Booklet.pdf

Pullen, J. P. (2014, November 4). 2016 Time Inc. Retrieved April 21, 2016, from Time Inc. Network: www.time.com

Rundle, M. (2014, June). What is Uber? And Why Do London Cabbies Hate It? Retrieved from The Huffington Post: http://www.huffingtonpost.co.uk/2014/06/11/what-is-uber_n_5483290.html.

Savignon, S. (1983). Communicative Competence: Theory and Classroom Practice. In Texts and Contexts in Second Language Learning (p. 9). Massachusetts: Addison-Wesley Publishing Company.

Selke, R., Hoon, A. L., \& Schaar, T. (2015). Using Apps to Improve Service Delivery in Malaysian Hotels: Guests' and Employees' Rationales. TEAM Journal of Hospitality and Tourism, 1-20.

Steinmetz, K. (2014, November). Looking for a Ride? Here's a List of Uber Alternatives. Retrieved from Times: http://time.com/3595621/uber-lyft-flywheel-sidecar/

Wright, C. (1992). Cambridge Language Consultants. Retrieved from The Benefits of ESP: www.camalang.com/art001.htm

Yi Liang, T. (2016, April 19). 1995-2016 Star Media Group Berhad. Retrieved April 21, 2016, from The Star Online: www.thestar.com.my

\section{Copyrights}

Copyright for this article is retained by the author(s), with first publication rights granted to the journal.

This is an open-access article distributed under the terms and conditions of the Creative Commons Attribution license (http://creativecommons.org/licenses/by/4.0/). 